\title{
SUSTAINABLE ADSORPTION REMOVAL OF NICKEL AND CHROMIUM ON ECO-FRIENDLY INDUSTRIAL WASTE: EQUILIBRIUM STUDY
}

\author{
Yehia H. Magdy ${ }^{1}$, Hossam Altaher ${ }^{2,}{ }^{凶}$, Anwar F. Al Yaqout ${ }^{3}$
}

https://doi.org/10.23939/chcht15.02.161

\begin{abstract}
Adsorption of nickel and chromium was investigated using fuller's earth. The experimental data were analyzed using five 2-parameter adsorption models and three 3-parameter models. The maximum adsorption capacities for nickel and chromium were 769 and $556 \mathrm{mg} / \mathrm{g}$, respectively. The Langmuir isotherm model was found to have the best fitting indicating monolayer adsorption. The adsorption was found to have an exothermic nature.
\end{abstract}

Keywords: adsorption, chromium, fuller's earth, isotherm, nickel, vegetable oil.

\section{Introduction}

Nickel and chromium are classified by many agencies as two of the most toxic heavy metals [1, 2]. Discharge of wastewater containing them to the environment without proper treatment represents a serious threat to the environment. These metals are soluble in the aqueous environment, increasing their threats since they will be readily available to humans, animals, and plants [3]. Hexavalent chromium has severe adverse health effects starting from allergic reactions to mutagenic and carcinogenic problems [4]. Nickel has acute neurotoxic and carcinogenic effects and it was found to be embryotoxic and teratogen [5]. The high concentration of nickel may cause dermatitis, chronic bronchitis, kidney disease, gastrointestinal distress, liver impairment and cardiovascular disease [6-8].

Many industrial effluents contain various concentrations of these metals. Chromium is present in high concentration in industries such as leather tanning, paints and pigments, textile, ceramics, wood processing,

\footnotetext{
${ }^{1}$ Department of Chemical Engineering, Faculty of Engineering, El-

Minia University P.O. Box 61511, Egypt

${ }^{2}$ Sustainable Solution Group, Al-Sharq, Ahmed Al-Jaber St., Al-Dira

Tower, P.O. Box 17886, Khalidiyah 72459, Kuwait

${ }^{3}$ Civil Engineering Department, Kuwait University, P.O. Box 5969,

Safat 13060, Kuwait

haltaher@hotmail.com

(c) Magdy Y., Altaher H., Al Yaqout A., 2021
}

electroplating, cooling, metal finishing, pulp and paper, cement manufacturing, alloy and steel manufacturing, fertilizer [9]. On the other hand, nickel can be found in the wastewater of many industries including electroplating, mining, smelting, paints, batteries, coinage, jewelry, stainless steel, and catalyst [10].

Various techniques are applied to remove metal ions from wastewater such as membrane technology, ion exchange, solvent extraction, chemical precipitation, coagulation/flocculation, electrochemical treatment, and adsorption [11, 12]. These methods have many disadvantages including generation of a considerable amount of sludge, high cost, and long-time required for such processes [13]. Among these several methods, adsorption has many advantages. The efficiency of removal even at low adsorbate concentration, the simplicity of operation, availability of adsorbents and possibility of their regeneration, low energy requirement are examples of the advantages of adopting adsorption as a removal techniques for many pollutants [14-18]. Several materials have been investigated by researchers as adsorbents [19]. However, it is very important to select the proper adsorbent that is suitable for the adsorption system under investigation. Such adsorbent must be cheap, efficient, and available in sufficient amount through the year [20,21].

Fuller's earth is natural widely available sedimentary clay that is known as bleaching clay. It belongs to the montmorillonite group having the general formula $\left(\mathrm{OH}_{4}\right) \mathrm{Si}_{8} \mathrm{O}_{20} \cdot n \mathrm{H}_{2} \mathrm{O}$. In addition to montmorillonite, fuller's earth may contain other constituents with different compositions including dolomite, quartz, and calcite. The crystal structure of montmorillonite is based on a threelayer type clay; two silica layers alternating with one alumina or silica layer [22]. Fuller's earth is also a solid waste that is produced from vegetable oils industry. Its main use in that industry is as a bleaching agent. In such an industry, it is used just once. After the bleaching stage of vegetable oils, the spent fuller's earth is separated by filtration and disposed of [23]. The worldwide generation of the spent bleaching material is estimated to be 2 million metric tons per year [23]. 
The aim of the present study was to investigate the adsorption removal of chromium and nickel from wastewater on fuller's earth to understand the adsorption mechanism and optimize the removal process. A further aim is to study the feasibility of using fuller's earth as an adsorbent. To accomplish this task, five 2-parameters and three 3-parameters isotherm models were used to analyze the experimental data.

\section{Experimental}

\subsection{Adsorbent}

Fuller's earth was procured from local fat and oil processing plant in Cairo, Egypt. It was received as a solid cake that is covered with oil and fats. The cake was washed thoroughly with ethanol, filtered, and air-dried at room temperature. This procedure was repeated three times to get rid of all impurities.

\subsection{Adsorbate}

Stock solutions of $1000 \mathrm{mg} / \mathrm{l}$ were prepared for both nickel and chromium by dissolving the metal salts (nickel sulfate and potassium dichromate) in bi-distilled water. Analytical grade salts (Merck) were used for the two ions. The wastewater was prepared by diluting the stock solutions with bi-distilled water. Initial and final concentrations of both nickel and chromium were determined using atomic absorption spectroscopy using a Scan AA4 instrument (Thermo Jarrell Ash, Franklin, MA, USA).

\subsection{Batch Study}

An adsorbent dosage of $0.1 \mathrm{~g}$ was added to $125 \mathrm{ml}$ conical flasks containing $50 \mathrm{ml}$ of the adsorbate solution. Every flask had a different known concentration (0 $24 \mathrm{mg} / \mathrm{l})$. The flasks were covered and agitated using a shaker for $12 \mathrm{~h}$ at a speed of $400 \mathrm{rpm}$. The solutions were filtered and the filtrate was analyzed for residual metal content. All experiments were performed at room temperature $(298 \pm 2 \mathrm{~K})$.

\subsection{Mathematical Models}

The experimental data were analyzed using Langmuir, Freundlich, Temkin, Dubinin-Radushkevich (DR), Redlich-Peterson, Toth and Sips adsorption isotherms. The equations of these models are represented in Table 1.

Equations and parameter for isotherm models

\begin{tabular}{|c|c|c|}
\hline Isotherm model & Parameters & Ref. \\
\hline $\begin{array}{l}\text { Langmuir isotherm } \\
q_{e}=q_{m} C_{e} /\left(K_{L}+C_{e}\right) \\
1 / q_{e}=1 /\left(q_{m}\right)+C_{e}\left(K_{L} / q_{m}\right) \\
R_{L}=1 /\left(1+K_{L} C_{o}\right)\end{array}$ & $\begin{array}{l}C_{0} \text { is initial concentration of the adsorbate, } \mathrm{mg} / \mathrm{l} ; C_{e} \text { is equilibrium } \\
\text { concentration of the adsorbate, } \mathrm{mg} / \mathrm{l} ; \mathrm{q}_{\mathrm{e}} \text { is adsorption capacity, } \\
\mathrm{mg} / \mathrm{g} ; q_{m} \text { is maximum adsorption capacity; } K_{L} \text { is constant related } \\
\text { to adsorption rate, } 1 / \mathrm{mg} ; \mathrm{R}_{\mathrm{L}} \text { is a dimensionless separation factor }\end{array}$ & {$[15]$} \\
\hline $\begin{array}{l}\text { Freundlich isotherm } \\
q_{e}=k_{f} C_{e}^{1 / n} \\
\ln q_{e}=\ln k_{f}+1 / n\left(\ln C_{e}\right)\end{array}$ & $\begin{array}{l}k_{f} \text { is constant related to the bonding energy; } n \text { is constant } \\
\text { identifying the adsorption intensity }\end{array}$ & {$[15]$} \\
\hline $\begin{array}{l}\text { Temkin isotherm } \\
q_{e}=B_{T} \ln \left(K_{T} C_{e}\right) \\
q_{e}=B_{T}\left(\ln K_{T}\right)+B_{T} \ln \left(C_{e}\right) \\
B_{T}=(R T) / b\end{array}$ & $\begin{array}{l}b \text { is Temkin constant related to the heat of adsorption, } \mathrm{J} / \mathrm{mol} ; K_{T} \text { is } \\
\text { equilibrium binding constant, } 1 / \mathrm{mg} ; R \text { is general gas constant } \\
(8.314 \mathrm{~J} / \mathrm{mol} \mathrm{K}), T \text { is absolute temperature, K }\end{array}$ & {$[15]$} \\
\hline $\begin{array}{l}\text { Dubinin-Radushkevich isotherm } \\
q_{e}=q_{m} \exp \left(-B \varepsilon^{2}\right) \\
\ln q_{e}=\ln q_{m}-B \varepsilon^{2} \\
\varepsilon=R T \ln (1+1 / C e) \\
E=1 /(2 B)^{0.5}\end{array}$ & $\begin{array}{l}B \text { is constant related to the mean free energy of adsorption per } \\
\text { mole of adsorbate; } E \text { is adsorption energy }\end{array}$ & {$[15]$} \\
\hline Redlich-Peterson isotherm $q_{e}=\frac{k_{R} C_{e}}{1+a_{R} C_{e}^{b_{R}}}$ & $k_{R}(1 / \mathrm{g}), a_{R}\left(\frac{l}{m g}\right)^{b_{R}}$ and $b_{R}$ are isotherm constants & {$[24]$} \\
\hline Toth isotherm $q_{e}=\frac{k_{t} C_{e}}{\left(a_{t}+C_{e}\right)^{1 / t}}$ & $\begin{array}{l}k_{t} \text { and } t \text { are constants related to adsorbate-adsorbent pairs; } a_{t} \text { is } \\
\text { constant related to surface coverage, } 1 / \mathrm{mg}\end{array}$ & {$[25]$} \\
\hline Sips isotherm $q_{e}=\frac{q_{m}\left(a_{s} C_{e}\right)^{n_{s}}}{1+\left(a_{s} C_{e}\right)^{n_{s}}}$ & $\begin{array}{l}n_{s} \text { is constant that is specific to the adsorption system, } a_{s} \text { is } \\
\text { constant related to the adsorption equilibrium }\end{array}$ & {$[25]$} \\
\hline
\end{tabular}




\section{Results and Discussion}

\subsection{Adsorbent}

Fuller's earth has many advantages over other potential adsorbents being commercially available with very low cost, non-toxic, and eco-friendly [26]. It is essential to understand the chemical and crystalline structure of the used adsorbent. These two properties are responsible for the adsorption of the adsorbate. The major part of fuller's earth is montmorillonite. The crystal structure of montmorillonite consists of three layers; two silica layers alternating with one alumina or silica layer. Oxygen atoms form a plan in the tetrahedral silica sheet in a layer that is called siloxane layer (basal plane). The main component of this clay is hydrous aluminum silicate $\left[\left(\mathrm{OH}_{4}\right) \mathrm{Si}_{8} \mathrm{O}_{20} \cdot n \mathrm{H}_{2} \mathrm{O}\right]$. The concentration of hydrous aluminum silicate varies from one ore to another. Other components may be present in the ore, e.g. calcite, dolomite, and quartz.

The charges of the clay minerals are of two types; surface charge and structural charge. The surface charge depends on the $\mathrm{pH}$ value of the surrounding environment of the clay. The structural charge is permanent and it is due to ion substitutions. The dominant-negative charge of the clay is due to the isomorphic substitution of $\mathrm{Si}_{4}$ by $\mathrm{Al}_{3}$ in the tetrahedral sheet [22]. This negative charge is responsible for adsorbing the positive species in the aqueous solution.

It is worth noting that washing the spent fuller's earth with alcohol will remove the major part of the coloring matter. However, certain basic dyes adhere strongly to fuller's earthdue to chemical forces and cannot be desorbed [27]. These adsorbed dyes may be responsible for the high adsorption capacity of the earth toward metal ions. Such dyes may form extra active sites which interact with metal ions and adsorb them. The physical properties of fuller's earth are presented in Table $2[28]$ and the molecular structure of aluminum silicate.

Table 2

Physical properties of fuller's earth

\begin{tabular}{|l|c|}
\hline \multicolumn{1}{|c|}{ Property } & Value \\
\hline Cation exchange capacity & $50-200 \mathrm{meq} / 100 \mathrm{~g}$ \\
\hline Exchangeable cations & $\mathrm{Na}^{+}, \mathrm{K}^{+}, \mathrm{H}^{+}, \mathrm{Mg}^{2+}, \mathrm{ca}^{2+}$ \\
\hline Surface area & $120-140 \mathrm{~m}^{2} / \mathrm{g}$ \\
\hline Mean equivalent diameters of pores & $190-200 \AA$ \\
\hline Particle size & $10 \mu \mathrm{m}$ \\
\hline Porosity & $60-70 \%$ \\
\hline
\end{tabular}

\subsection{Adsorption Study}

Fig. 1 depicts the adsorption behavior of both nickel and chromium on the surface of fuller's earth. As clear from the plots, there are two stages of adsorption. In the initial stage, a considerably rapid rise in adsorption with increasing concentration of adsorbate can be observed. In the second stage, a plateau that is nearly horizontal is obtained where saturation of the active sites on the surface of adsorbent is attained. According to Giles classification, this is typical for Type I (L class) isotherms. This type of isotherms assumes a monolayer adsorption [29]. It can be also noticed that the chromium ions reach the plateau at a lower initial concentration with lower adsorption capacities indicating lower affinity of adsorbent compared to nickel ions.

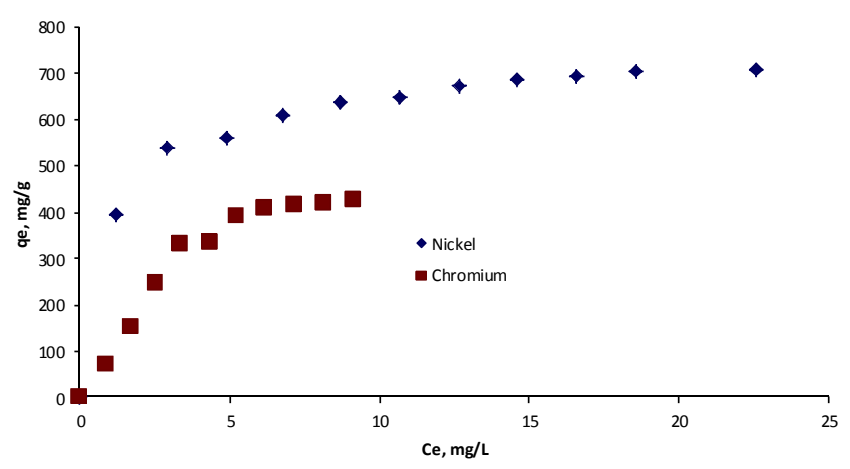

Fig. 1. Adsorption isotherms for nickel and chromium onto fuller's earth

\subsection{Two-Parameters Adsorption Isotherms Models}

\subsubsection{Langmuir model}

According to this model, the uptake of the adsorbate species is due to the attraction between homogeneous active sites on the surface of the adsorbent and the adsorbate species. This attraction results in the formation of a monolayer of adsorbate on the surface of the adsorbent. Furthermore, the model assumes that adsorbed species do not migrate from one active site to another. The value of separation factor $\left(R_{L}\right)$ determines the favorability of the adsorption process; adsorption is irreversible when $R_{L}=0$, favorable when $0<R_{L}<1$, linear for $R_{L}=1$, and unfavorable when $R_{L}>1$.

Table 3 lists the parameters obtained from fitting the experimental data to the linear form of the Langmuir model. The good fitting of the experimental data to the model is clear from the high correlation coefficient $\left(R^{2}\right)$ for the two adsorption systems; 0.999 and 0.978 for nickel and chromium, respectively. Compared to other investigated models, Langmuir equation represents the best fit of experimental data. The adsorption uptake of nickel is much higher than that of chromium; 769 and $556 \mathrm{mg} / \mathrm{g}$, respectively. Furthermore, the values of $R_{L}$ for 
both adsorption systems are in a favorable range. The value of $R_{L}$ for nickel; being much less than that of chromium indicate the high affinity of nickel to the sorption sites.

The mean equivalent diameters of fuller's earth pores are in the range of 190-200 $\AA$ [28], while the ionic radii of nickel and dichromate ions are 0.69 and $2.92 \AA$ Á, respectively [30]. So the pore diameter of fuller's earth does not represent any restriction for nickel and chromium adsorption. On the other hand, it has been mentioned before the surface of fuller's earth carries negative charges. These negative charges attract the positive nickel ions in the solution rather than the negative dichromate ions. The latter may be attracted to the edge face of the surface of fuller's earth. This edge face carries a positive charge at $\mathrm{pH}$ less than 7 [28], which is the case of the current research. The dye molecules pre-adsorbed on the surface of the adsorbent may also be responsible for the enhancement of adsorption capacity due to the intermolecular interactions with metal ions (synergistic effect) [31]. This is in accordance with the results of Bhattacharya et al. [32] who indicated that the adsorption capacity of hexavalent chromium on fuller's earth was $23.58 \mathrm{mg} / \mathrm{g}$.

Table 3

Linear adsorption parameters for the applied 2-parameters adsorption models

\begin{tabular}{|c|c|c|c|c|c|c|c|c|c|c|c|c|c|}
\hline Isotherm & \multicolumn{4}{|c|}{ Langmuir } & \multicolumn{3}{|c|}{ Freundlich } & \multicolumn{4}{c|}{ Temkin } & \multicolumn{4}{c|}{$D-R$} \\
\hline & $R^{2}$ & $q_{m}$ & $b$ & $R_{L}$ & $R^{2}$ & $n$ & $k_{f}$ & $R^{2}$ & $B_{T}$ & $K_{T}$ & $R^{2}$ & $q_{m}$ & $E$ \\
\hline Nickel & 0.999 & 769 & 0.684 & 0.057 & 0.949 & 5.25 & 411 & 0.977 & 106 & 1.37 & 0.982 & 5 & 9.13 \\
\hline Chromium & 0.978 & 556 & 0.375 & 0.211 & 0.910 & 1.36 & 104 & 0.973 & 168 & 5.95 & 0.928 & 0.09 & 9.13 \\
\hline
\end{tabular}
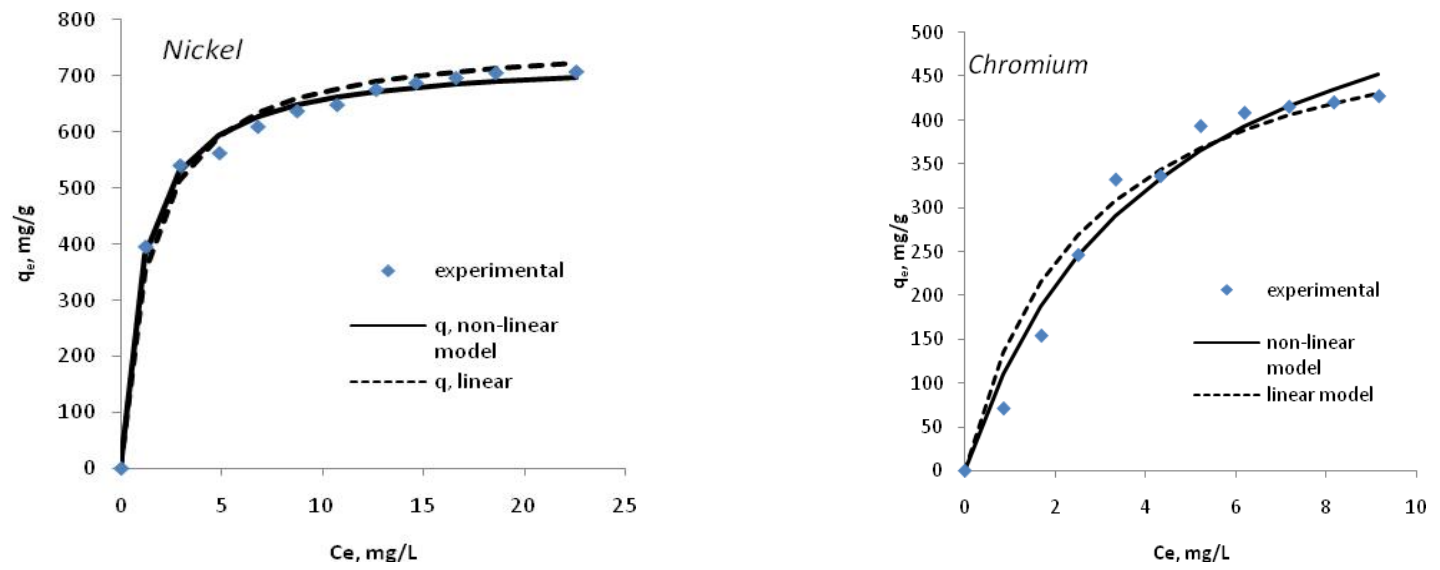

Fig. 2. Fitting of experimental and model data to Langmuir isotherm for adsorption of nickel and chromium

Nonlinear adsorption constants for the applied 2-parameters adsorption models

\begin{tabular}{|l|c|c|}
\hline \multicolumn{1}{|c|}{ Isotherm } & Nickel & Chromium \\
\hline \multicolumn{3}{|c|}{ Langmuir } \\
\hline SSD & 2621 & 6392 \\
\hline$q_{m}$ & 731 & 664 \\
\hline$K_{L}$ & 0.888 & 0.234 \\
\hline$R_{L}$ & 0.045 & 0.299 \\
\hline \multicolumn{3}{|c|}{ Freundlich } \\
\hline SSD & 4107 & 14104 \\
\hline$n$ & 5.64 & 1.89 \\
\hline$k_{f}$ & 424 & 146 \\
\hline SSD & Temkin \\
\hline$B_{T}$ & 2064 & 4555 \\
\hline$K_{T}$ & 106 & 161 \\
\hline
\end{tabular}


Adsorption parameters obtained from fitting the experimental data to the non-linear form of the Langmuir model are introduced in Table 4 while the plots are depicted in Fig. 2. It is clear that the transformation of the nonlinear to linear form did not significantly affect Langmuir parameters. For instance, the adsorption capacity of nickel decreased from 769 to $731 \mathrm{mg} / \mathrm{g}(5 \%$ change), while $R_{L}$ decreased from 0.057 to 0.045 . A similar change can be observed for the chromium adsorption system. However, the linear plots fit the experimental data better than the non-linear plots for both nickel and chromium. This result is supported by the high values of the sum of squared deviation (SSD) which are used to assess the fitting procedure. A similar result was obtained by Parimal et al. [33] when studying the adsorption of metal ions on aluminosilicate mineral.

\subsubsection{Freundlich model}

Freundlich model assumes a heterogeneous adsorbent surface. This model can be applied in case of low to intermediate concentrations of adsorbates. The parameter $\mathrm{n}$ is related to the intensity of adsorption. If the value of $n$ is greater than 1 then the adsorption is favorable [34]. The parameters of the model obtained from fitting the experimental data to the linear and non-linear forms are presented in Tables 3 and 4 while the plots are presented in Fig. 3. The values of correlation coefficients $\left(R^{2}\right)$ obtained from linear regression for both nickel and chromium are less than fitting the data to the Langmuir model suggesting a better fit of the latter. However, the values of the parameter $n$ are greater than 1 for both nickel and chromium which assures the favorability of the adsorption system.

Comparing the parameters obtained from linear and non-linear regression show little difference in the case of nickel adsorption system and a considerable difference in the case of the chromium adsorption system. The plots in Fig. 3, representing the experimental data and fitting the data to the model, and the high values of SSD suggest that the linear fitting better describes the experimental data.
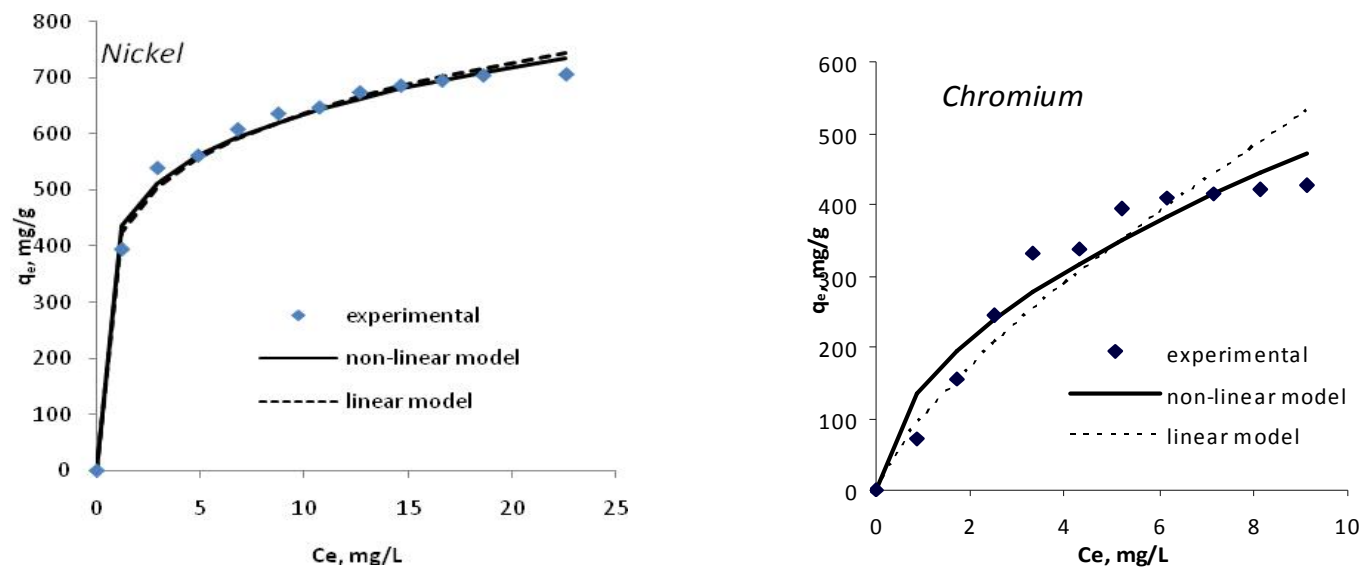

Fig. 3. Fitting of experimental and model data to Freundlich isotherm for adsorption of nickel and chromium
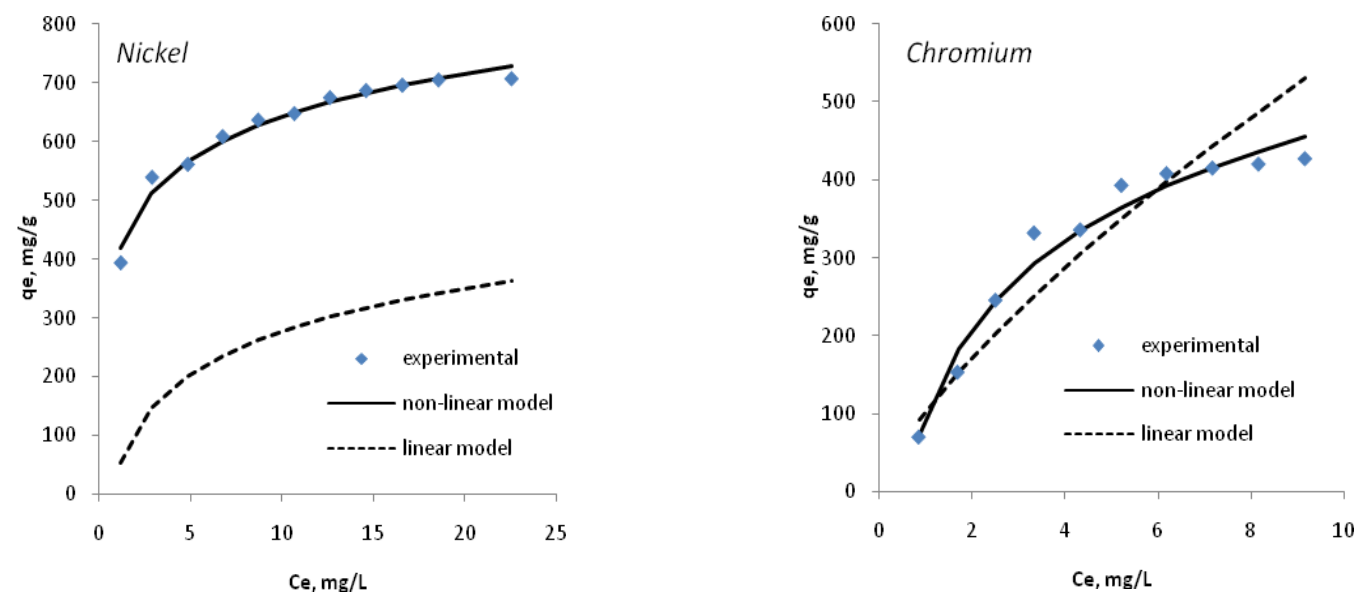

Fig. 4.Fitting of experimental and model data to Temkin isotherm for adsorption of nickel and chromium 


\subsubsection{Temkin model}

Temkin model assumes that the change in the heat of adsorption is linear rather than logarithmic which is opposite to Freundlich assumptions. The parameters obtained from fitting the experimental data to both linear and non-linear forms of the model are introduced in Tables 3 and 4, while the plots are shown in Fig. 4. The plots in Fig. 4 indicate that the non-linear form of the model fits the data better than the linear form. The parameter $b$ is very important since it is related to the heat of adsorption. The calculated values of the parameter $b$ are 1.4 and $0.8 \mathrm{~kJ} / \mathrm{mol}$ for nickel and chromium, respectively. Since these values are positive, the adsorption has exothermic nature [35].

\subsubsection{Dubinin-Radushkevich model}

This model assumes Gaussian energy distribution onto a heterogeneous surface. It is suitable for describing the adsorption of moderate to high concentration of adsorbates. The parameter $E$ is the mean free energy of adsorption and it helps to identify the type of adsorption: physical or chemical. If $E>16 \mathrm{~kJ} / \mathrm{mol}$, the adsorption process is chemical, if $E<8 \mathrm{~kJ} / \mathrm{mol}$, the adsorption process is physical, and if $8<E<16$, the adsorption process is ion exchange. The parameters obtained from fitting the data to this model is presented in Table 3. The values of $E$ for both nickel and chromium suggest a chemical nature of the adsorption process [24].

\subsection{Three-Parameters Isotherms}

Redlich-Peterson isotherm has the features of both Langmuir and Freundlich isotherms. So it can be applied in homogeneous and heterogeneous systems. At high concentration, it approximates to the Freundlich model while at low concentration the model approximate to Henry's law. Fig. 5 represents fitting the experimental data to the non-linear form of the model whereas the parameters obtained from that fitting are introduced in Table 5. The high values of SSD obtained for both nickel and chromium suggest weak fitting to the model. As shown in Table 5, the ratios $k_{R} / a_{R}$ are not similar to $k_{f}$. That supports the fact that the experimental data did not fit well to Freundlich isotherm and that Langmuir model is a better choice. Moreover, the values of the exponent $b_{R}$ for both nickel and chromium do not have the same correspondence to the exponent $n$ obtained from Freundlich isotherm.

Toth model is an empirical equation that modifies the Langmuir equation. This model satisfies the two end limit of low and high concentrations and it was found useful in describing heterogeneous adsorption systems [36]. The parameter $t$ is related to the heterogeneity of the adsorption system. If the experimental data well fit the model, the value of $t$ will be less than 1 . If the value of $t$ is unity the isotherm reduces to Langmuir equation. Moreover, Toth model contains the parameter $k_{t}$ that estimates the maximum adsorption capacity [37]. Fig. 6 represents the fitting of experimental data to Toth model and the parameters obtained from this fitting are introduced in Table 5. It is clear from the values of SSD that the fitting is considerable for the nickel adsorption system. The value of the parameter $t$ is near to unity indicating homogeneous adsorption system. The maximum adsorption capacity obtained from this model $(557 \mathrm{mg} / \mathrm{g})$ is near to that value obtained from Langmuir isotherm $(769 \mathrm{mg} / \mathrm{g})$. On the other hand, poor-fitting is observed for the chromium adsorption system.

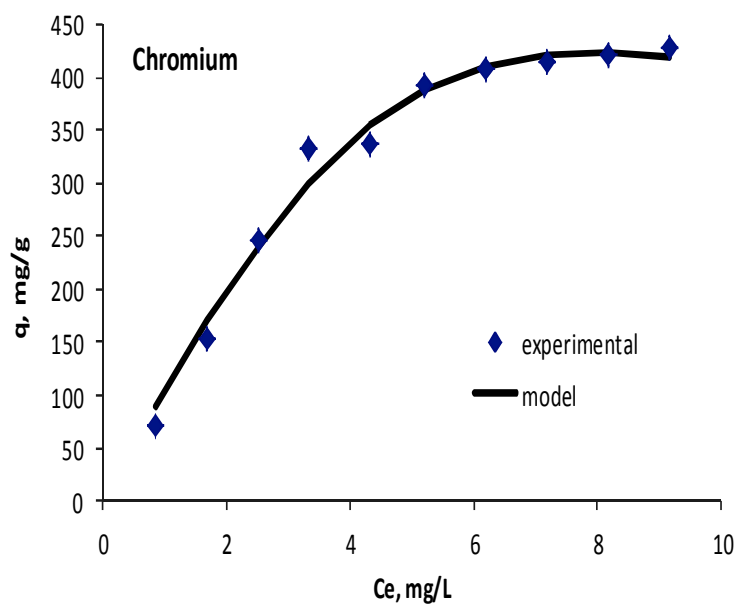

Fig. 5. Fitting of experimental and model data to Redlich-Peterson isotherm for adsorption of nickel and chromium

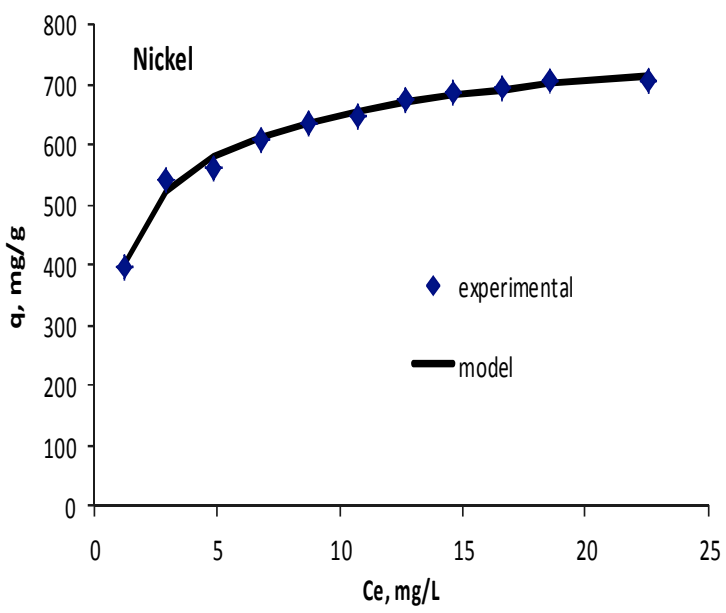


Sustainable Adsorption Removal of Nickel and Chromium on Eco-Friendly Industrial Waste...

Table 5

Nonlinear adsorption parameters for the applied three-parameters adsorption models

\begin{tabular}{|c|c|c|}
\hline Isotherm & Nickel & Chromium \\
\hline \multicolumn{3}{|c|}{ Redlich-Peterson } \\
\hline SSD & 947 & 2115 \\
\hline$k_{R}$ & 1043 & 105 \\
\hline$a_{R}$ & 1.81 & 0.014 \\
\hline$b_{R}$ & 0.92 & 2.05 \\
\hline \multicolumn{3}{|c|}{ Toth } \\
\hline SSD & 935 & 3639 \\
\hline$k_{t}$ & 557 & 2.6Е09 \\
\hline$a_{T}$ & 0.564 & 36.6 \\
\hline$t$ & 1.096 & 0.214 \\
\hline \multicolumn{3}{|c|}{ Sips } \\
\hline SSD & 1043 & 1314 \\
\hline$q_{m}$ & 827 & 459 \\
\hline$a_{s}$ & 0.755 & 0.440 \\
\hline$n_{s}$ & 0.644 & 1.954 \\
\hline
\end{tabular}
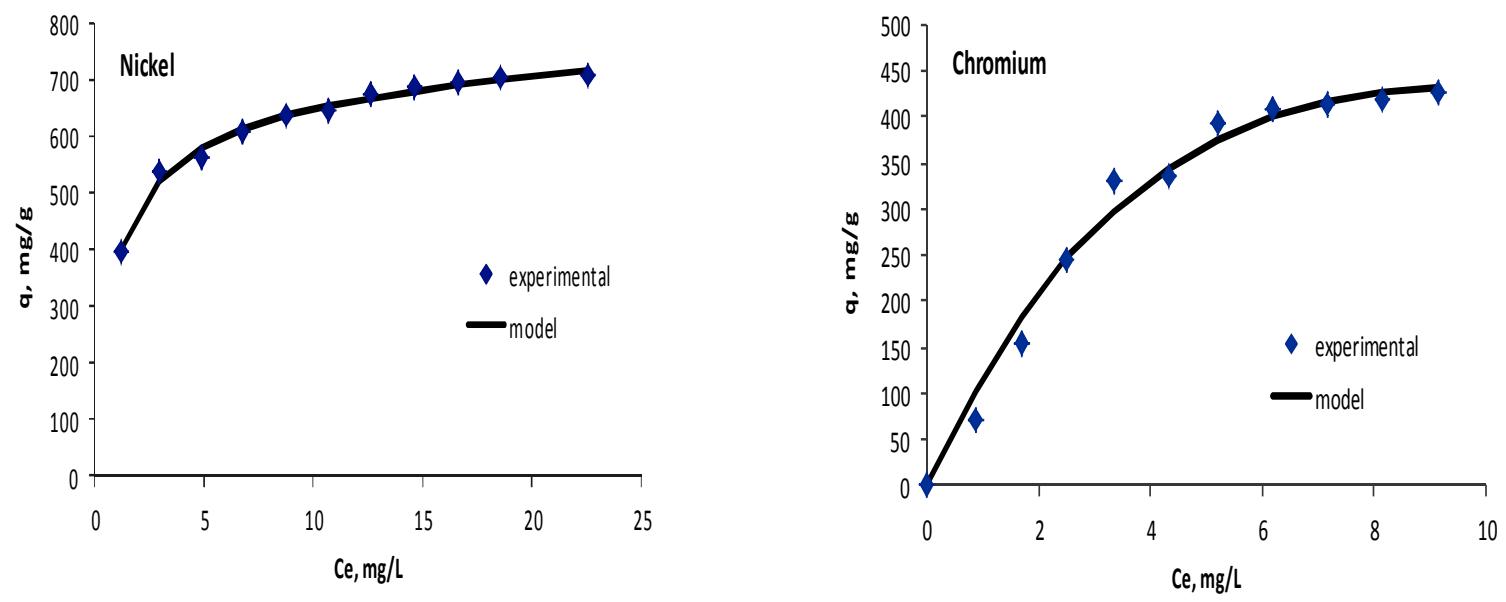

Fig. 6. Fitting of experimental and model data to Toth isotherm for adsorption of nickel and chromium
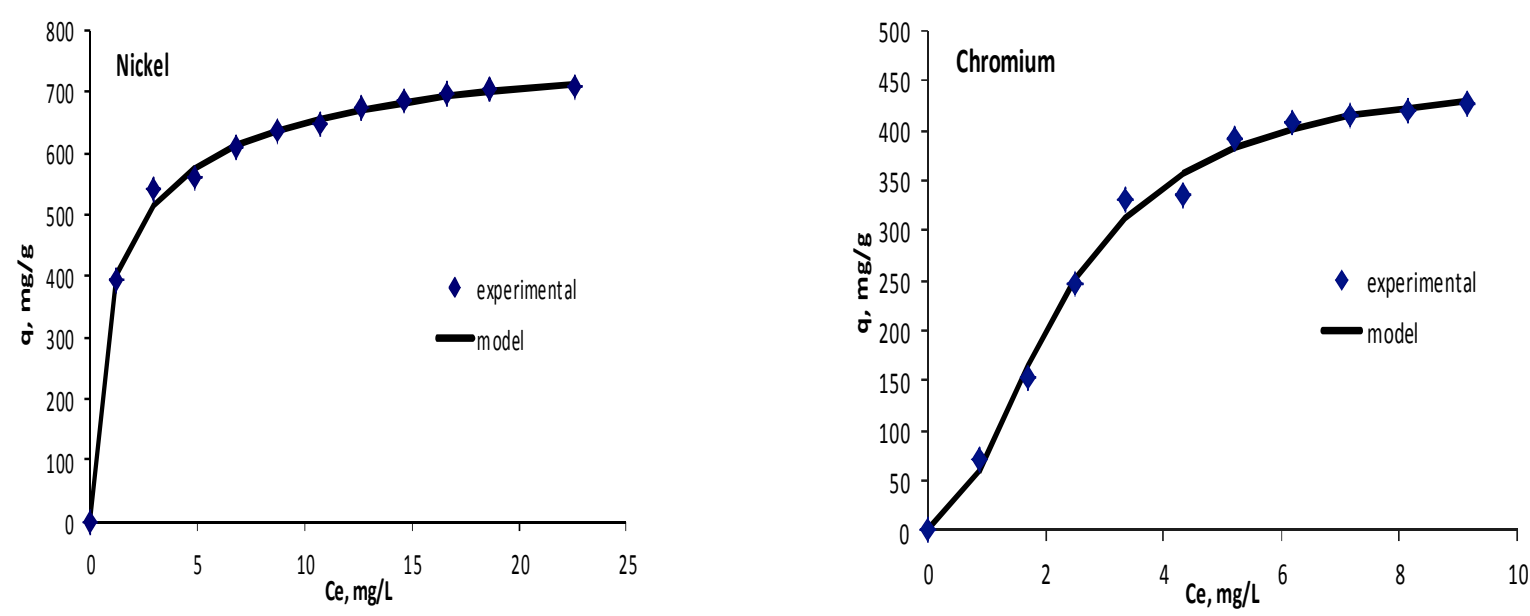

Fig. 7. Fitting of experimental and model data to Sips isotherm for adsorption of nickel and chromium 
Sips model is a combination of Langmuir and Freundlich isotherms. This model is suitable for explaining adsorption in heterogeneous systems. At low concentration, it reduces to the Freundlich model while at high concentration it is similar to the Langmuir model [38]. Fig. 7 illustrates the fitting of experimental data to this model while non-linear regression parameters are introduced in Table 5. Based on the values of SSD for two adsorption systems, Sips model show the same weak fitting of the experimental data. However, the values of adsorption capacity obtained using the Sips model are consistent with that obtained from Langmuir isotherm.

\subsection{Comparison with Other Adsorbents}

Table 6 introduces a comparison between the maximum adsorption capacity of nickel and chromium onto fuller's earth with other adsorbents in the literature. It is obvious that fuller's earth has the highest adsorption capacity compared with other documented adsorbents. To the best of our knowledge, and according to the extensive literature review, fuller's earth can be considered the best adsorbent for both nickel and chromium.

Table 6

Comparison of adsorption capacity of fuller's earth with other adsorbents

\begin{tabular}{|c|c|c|c|}
\hline Metal & Adsorbent & $q_{e}, \mathrm{mg} / \mathrm{g}$ & Ref. \\
\hline Nickel & Biomass-based activated carbon & 141 & {$[5]$} \\
\cline { 2 - 4 } & Modified peanut shell biochar & 87.15 & {$[39]$} \\
\cline { 2 - 4 } & Sawdust based activated carbon & 16.47 & {$[40]$} \\
\cline { 2 - 4 } & Sodium polyacrylate grafted activated carbon & 55.7 & {$[41]$} \\
\cline { 2 - 4 } & Carbon nanotubes & 19.86 & {$[42]$} \\
\cline { 2 - 4 } & $\mathrm{Fe}_{2} \mathrm{O}_{3}$-carbon foam & 6.4 & {$[43]$} \\
\cline { 2 - 4 } & Modified activated carbon & 25.65 & {$[8]$} \\
\cline { 2 - 4 } & Non-living Streptomyces Roseorubens SY & 208.39 & {$[13]$} \\
\cline { 2 - 4 } & Activated carbon from spent coffee & 51.91 & {$[11]$} \\
\cline { 2 - 4 } & Silica-based hybrid adsorbents & 49.24 & {$[12]$} \\
\hline Chromium & Fuller's earth & 769 & This work \\
\cline { 2 - 4 } & Activated carbon & 36.01 & {$[44]$} \\
\cline { 2 - 4 } & Waste tire & 214.72 & {$[45]$} \\
\cline { 2 - 4 } & Chitosan-stabilized nanostructured iron oxide & 237 & {$[46]$} \\
\cline { 2 - 4 } & Biochar & 21.3 & {$[47]$} \\
\cline { 2 - 4 } & Rutin resin & 41.6 & {$[48]$} \\
\cline { 2 - 4 } & Activated carbon & 140.8 & {$[49]$} \\
\cline { 2 - 4 } & Bone char & 4.8 & {$[4]$} \\
\cline { 2 - 4 } & Lignin-based resin & 57.681 & {$[50]$} \\
\cline { 2 - 4 } & Ash gourd peel waste & 18.7 & {$[51]$} \\
\cline { 2 - 4 } & Teff straw & 56 & {$[52]$} \\
\cline { 2 - 4 } & Fuller's earth & 556 & This work \\
\hline
\end{tabular}

\section{Conclusions}

The adsorption of chromium and nickel ions onto fuller's earth was found to be of chemical nature. The experimental data best fitted to the Langmuir model. The results show that the maximum adsorption capacity using fuller's earth is much higher than other adsorbents mentioned in the literature. Such high adsorption capacity for both adsorbates is suggesting fuller's earth to be a potential adsorbent for similar heavy metals.

\section{References}

[1] ATSDR. Priority List of Hazard Substances. Agency Toxic Subst Dis Regist (ATSDR) Dep Heal Hum Serv 2015. https://www. atsdr.cdc.gov/spl/resources/atsdr_2015_spl_support_document.pdf
[2] Water Quality Standard Handbook, Ch. 3, 2012, 56.

https://www.epa.gov/sites/production/files/2014-

10/documents/handbook-chapter3.pdf

[3] Dwivedi A., Dubey S., Sillanpää M. et al.: Chem. Eng. J., 2015, 281, 713. https://doi.org/10.1016/j.cej.2015.07.004

[4] Hyder A., Begum S., Egiebor N.: J. Environ. Chem. Eng., 2015, 3, 1329. https://doi.org/10.1016/j.jece.2014.12.005

[5] Anoop Krishnan K., Sreejalekshmi K., Baiju R.: Bioresour. Technol., 2011, 102, 10239.

https://doi.org/10.1016/j.biortech.2011.08.069

[6] Belova D., Lakshtanov L., Carneiro J., Stipp S.: J. Contam. Hydrol., 2014, 170, 1. https://doi.org/10.1016/j.jconhyd.2014.09.007 [7] Fouladgar M., Beheshti M., Sabzyan H.: J. Mol. Liq., 2015, 211, 1060. https://doi.org/10.1016/j.molliq.2015.08.029

[8] Li Y., Zhang J., Liu H.: Powder Technol., 2018, 325, 113. https://doi.org/10.1016/j.powtec.2017.10.051

[9] Abubeah R., Altaher H., Khalil T.: Environ. Eng. Manag. J., 2018, 17, 1621. https://doi.org/10.30638/eemj.2018.161 
[10] Najafi F., Moradi O., Rajabi M. et al.: J. Mol. Liq., 2015, 208, 106. https://doi.org/10.1016/j.molliq.2015.04.033

[11] Hernández Rodiguez M., Yperman J., Carleer R. et al.: J. Environ. Chem. Eng., 2018, 6, 1161.

https://doi.org/10.1016/j.jece.2017.12.045

[12] Xu M., Liu J., Hu K. et al.: Chinese J. Chem. Eng., 2016, 24, 1353. https://doi.org/10.1016/j.cjche.2016.05.028

[13] Long J., Gao X., Su M. et al.: Colloid Surface A, 2018, 548,

125. https://doi.org/10.1016/j.colsurfa.2018.03.040

[14] Altaher H.: Glob. Nest J., 2014, 16, 707.

https://doi.org/10.30955/gnj.001385

[15] Khalil T., Altaher H., Abubeah R.: Environ. Eng. Manag. J., 2016, 15, 2719. https://doi.org/10.30638/eemj.2016.299

[16] Altaher H., Al-Oufi F., Magdy Y., Hassan M.: Yanbu J. Eng. Sci., 2015, 11, 29.

[17] Ebrahiem E., Altaher H., Abdelghany E., Magdy Y.: J. Hazard. Toxic Radioact. Waste, 2018, 22.

https://doi.org/10.1061/(ASCE)HZ.2153-5515.0000401

[18] Altaher H., Dietrich A.: Water Sci. Technol., 2014, 69, 31.

https://doi.org/10.2166/wst.2013.522

[19] Magdy Y., Altaher H.: J. Environ. Chem. Eng., 2018, 6, 834. https://doi.org/10.1016/j.jece.2018.01.009

[20] Altaher H., Khalil T., Abubeah R.: Color. Technol., 2014, 130, 205. https://doi.org/10.1111/cote.12086

[21] Ashour I., Altaher H., Sawalha F., Maraqah M.: Technol. Dev., 2015, 34, 16. https://doi.org/10.3923/std.2015.16.26

[22] Shah J., Rasul Jan M., Zeeshan M., Imran M.: Appl. Clay. Sci., 2017,143, 227. https://doi.org/10.1016/j.clay.2017.03.040

[23] Beshara A., Cheeseman C.: Waste Manag., 2014, 34, 1770. https://doi.org/10.1016/j.wasman.2014.04.021

[24] Magdy Y., Altaher H., Abdelghany E.: J. Mater. Environ. Sci., 2018, 9, 570. https://doi.org/10.26872/jmes.2018.9.2.63

[25] Magdy Y., Altaher H., ElQada E.: Appl. Water Sci., 2018, 8, 26. https://doi.org/10.1007/s13201-018-0666-1

[26] Rekunge D., Indalkar K., Chaturbhuj G.: Tetrahedron. Lett., 2016, 57, 5815. https://doi.org/10.1016/j.tetlet.2016.11.049

[27] List G.: Bleaching and Purifying Fats and Oils: Theory and Practice, $2^{\text {nd }}$ edn. AOCS Publishing, New York 2010.

https://doi.org/10.1201/b10513

[28] Bajpai A., Vishwakarma N.: Colloid Surface A, 2003, 220,

117. https://doi.org/10.1016/S0927-7757(03)00073-6

[29] Khalfaoui M., Knani S., Hachicha M., Lamine A.: J. Colloid Interface. Sci., 2003, 263, 350. https://doi.org/10.1016/S00219797(03)00139-5

[30] Roobottom H., Jenkins H., Passmore J., Glasser L.: J. Chem. Educ., 1999, 76, 1570. https://doi.org/10.3109/13880200903078495 [31] Flores López S., Moreno Virgen M., Hernández Montoya V. et al.: J. Mol. Liq., 2018, 269, 450.

https://doi.org/10.1016/j.molliq.2018.08.063

[32] Bhattacharya A., Naiya T., Mandal S., Dasa S.: Chem. Eng. J., 2008, 137, 529.

[33] Parimal S., Prasad M., Bhaskar U.: Ind. Eng.Chem. Res., 2010, 49, 2882. https://doi.org/10.1021/ie9013343

[34] Fan C., Zhang Y.: J. Geochemical Explor., 2018, 188, 95.

https://doi.org/10.1016/j.gexplo.2018.01.020

[35] Hamdaoui O.: J. Hazard. Mater., 2006, 135, 264.

https://doi.org/10.1016/j.jhazmat.2005.11.062

[36] Podder M., Majumder C.: Compos. Interface., 2016, 23, 327.

https://doi.org/10.1080/09276440.2016.1137715
[37] Whittaker P., Wang X., Regenauer-Lieb K., Chua H.T.: Phys. Chem. Chem. Phys., 2013, 15, 473.

https://doi.org/10.1039/C2CP41756A

[38] Tzabar N., ter Brake H.: Adsorption, 2016, 22, 901.

https://doi.org/10.1007/s10450-016-9794-9

[39] An Q., Jiang Y-Q., Nan H-Y. et al.: Chemosphere, 2019, 214,

846. https://doi.org/10.1016/j.chemosphere.2018.10.007

[40] Mathangi J., Sadeesh Sharma M., Mercy Jacquline B., Helen

Kalavathy M.: Vacuum, 2018, 158, 236.

https://doi.org/10.1016/j.vacuum.2018.09.056

[41] Ewecharoen A., Thiravetyan P., Wendel E., Bertagnolli H.: J.

Hazard. Mater., 2009, 171, 335.

https://doi.org/10.1016/j.jhazmat.2009.06.008

[42] He J., Shang H., Zhang X., Sun X.: Appl. Surf. Sci., 2018, 428,

110. https://doi.org/10.1016/j.apsusc.2017.09.123

[43] Lee C., Lee S., Park J. et al.: Chemosphere, 2017, 166, 203.

https://doi.org/10.1016/j.chemosphere.2016.09.093

[44] Enniya I., Rghioui L., Jourani A.: Sustain. Chem. Pharm., 2018, 7, 9. https://doi.org/10.1016/j.scp.2017.11.003

[45] Bhatti I., Ahmad N., Iqbal N. et al.: J. Environ. Chem. Eng., 2017, 5, 2740. https://doi.org/10.1016/j.jece.2017.04.051

[46] Chagas P., de Carvalho L., Caetano A. et al.: J.Environ. Chem. Eng., 2018, 6,1008. https://doi.org/10.1016/j.jece.2018.01.026

[47] Choudhary B., Paul D.: J. Environ. Chem. Eng., 2018, 6, 2335. https://doi.org/10.1016/j.jece.2018.03.028

[48] Fathy N., El-Wakeel S., Abd El-Latif R.: J. Environ. Chem. Eng., 2015, 3,1137. https://doi.org/10.1016/j.jece.2015.04.011 [49] Gueye M., Richardson Y., Kafack F., Blin J.: J. Environ. Chem. Eng., 2014, 2, 273.

https://doi.org/10.1016/j.jece.2015.04.011

[50] Liang F., Song Y., Huang C. et al.: J. Environ. Chem. Eng., 2013, 1, 1301. https://doi.org/10.1016/j.jece.2013.09.025

[51] Sreenivas K., Inarkar M., Gokhale S., Lele S.: J. Environ.

Chem. Eng., 2014, 2, 455.

https://doi.org/10.1016/j.jece.2014.01.017

[52] Wassie A., Srivastava V.: J. Environ. Chem. Eng., 2016, 4,

1117. https://doi.org/10.1016/j.jece.2016.01.019

Received: August 20, 2019 / Revised: September 30, 2019 / Accepted: January 12, 2020

\section{СТАБІЛЬНЕ АДСОРБЦЙНЕ ВИДАЛЕННЯ НІКЕЛЮ ТА ХРОМУ ЗА ДОПОМОГОЮ ЕКОЛОГІЧИХ ПРОМИСЛОВИХ ВІДХОДІВ: РІВНОВАЖНІ ДОСЛІДЖЕННЯ}

\footnotetext{
Анотація. Досліджено адсорбиію нікелю та хрому з використанням відбілювальної глини. Експериментальні дані проаналізовані за допомогою 5-параметричних моделей адсорбиї та трьох 3-параметричних моделей. Максимальна адсорбиійна здатність для нікелю та хрому становила відповідно 769 та 556 мг/2. Встановлено, що модель ізотерми Ленгмюра найкраще підходить для одношарової адсорбиії. Виявлено, щэо адсорбиія має екзотермічну природу.
}

Ключові слова: адсорбчія, хром, відбілювальна глина, ізотерма, нікель, олія. 